ROCZNIKI KULTUROZNAWCZE

Tom/Vol. XII, numer/number $2-2021$

DOI: http://doi.org/10.18290/rkult21122-3

MARIIA BARDYN

\title{
CONFESSIONAL POLYVARIANCE OF CHRISTIAN APOCALYPTIC: COMMON AND DISTINCTIVE FEATURES
}

\author{
MATERIALS AND METHODS
}

This work relies on general scientific and special research methods. The main research approach was systematic, and a comparative historical method was used as well, enabling an identification of the main features, genesis and distribution of apocalyptic literary tradition in the Christian culture system, in comparing apocalyptic themes, motifs and images in the diferent religions.

\section{INTRODUCTION}

Nowadays we notice information about the fate of our civilization against the background of various global and space threats. The TV screen is sorting through all sorts of options for the end of the world so that it is becoming more like a kind of propaganda campaign. And in this again there is a connection with the plans for the speedy reign of the Antichrist. The Book of Revelation describes terrible cataclysms - both the previous rule of the Antichrist and the accompanying period of his reign. All of them, according to the Apocalypse, are nothing but the judgments of God over men, who rejected salvation in the Lord Jesus Christ.

It is safe to say that it was the Bible that gave mankind the idea of the "end of the world." The New Testament further concretizes the meaning of history. A new countdown has taken place since the birth of Jesus Christ: "before and after the birth of Christ."

MARIIA BARDYN - H. S. Skovoroda Philosophy Institute of the National Academy of Sciences of Ukraine; e-mail: marysssik@gmail.com; ORCID: https://orcid.org/0000-0002-0126-971X. 
However, Christ said that the "after" age will not last forever and that one day the world in which we now live will perish. The end of the world is discussed in more detail in the New Testament book of the Apocalypse. This is the last book of the Bible, which according to Scripture was written by one of the Twelve Apostles, John the Theologian (author of the fourth Gospel) in the late first century $\mathrm{AD}$, although there are still other points of view.

People are concerned about the onset of the Apocalypse; this theme is widely reflected in many areas of art, and religion is not left out, either. The clergy interpret all events and processes in terms of Christianity, morality, and culture that have developed over time.

Representatives of various denominations are actively using a variety of scientific methods of critical Bible study. This makes it possible to avoid the absolutization of traditional methods: literal, allegorical, etc. The position according to which different approaches and methods can interact and complement each other is considered fruitful. ${ }^{1}$

\section{APOCALYPTIC VIEWS OF RUSSIAN ORTHODOX PRIESTS}

In the context of our research topic, it should be noted that the problem of the Second Coming of Christ, the Resurrection of the dead and the life to come, referred to in the Revelation are dogmas of the Orthodox faith and were adopted at the Council of Nicaea (325).

Published in 2000, the book of Archpriest Men - a priest of the Russian Orthodox Church, theologian, preacher who reads the Apocalypse, reproduces the text of his conversations on the interpretation of symbolic images of the Revelation. $^{2}$

Speaking of Men's interpretation of the Apocalypse, it is necessary to remember two theses from which all of his subsequent reflections proceeded. The Apocalypse is a topic that will always be relevant, because our life is imperfect, sinful, and accordingly we are afraid of retribution. The second thesis of the priest is a special understanding and interpretation of the Apo-

\footnotetext{
${ }^{1}$ Serhiy HolovashchenKo, Doslidzhennia ta vykladannia Biblii v Kyivskii dukhovnii akademii XIX-pochatku XX st. (Kyiv: Vydavnychyi viddil Ukrainskoi Pravoslavnoi Tserkvy, 2012), 356.

${ }^{2}$ Aleksandr MEN, Chytaia Apokalypsys (Moscow: Fond ymeny Aleksandra Menia, 2000), 262.
} 
calypse. Men is convinced that the Apocalypse is faith and hope that may, of course, seem absurd at first glance. ${ }^{3}$

Men emphasizes the allegorical-symbolic interpretation of the paintings of the Apocalypse, where it is important to understand the meaning of the images. Besides, the author notes that the Apocalypse is a permanent reality that is being revived. Therefore, humanity periodically experiences these apocalyptic prophecies. God's judgment continues constantly and thus will continue in the future.

Andrei Kuraev is a Russian public and church figure, writer, and missionary. The Archdeacon of the Russian Orthodox Church of the Moscow Patriarchate notes that there are two types of resurrection: the first is an inner, personal revival in spirit and faith while still alive; the second is on the verge of history, the universal resurrection, which also concerns the body. Kuraev says: "Resurrection can be understood in two ways: one by which we "resurrect' from earthly things, in the spirit, according to our own decision and faith; in it, we see heavenly things and strive for future things; secondly, it is a universal resurrection that will take place in the flesh."

The Apocalypse reveals the general course of the historical process from the time of the Savior to the end of the world and indicates the total number of periods of evolution that the Church and the world must go through, but does not indicate the date of the Antichrist's coming and the Last Judgment.

Kuraev deduces the main feature of the Christian apocalypse: people will choose a new faith and new rulers, will open the world for the "Prince of Darkness," because good cannot forcibly penetrate human consciousness, and there are no limits to evil. Also, he notes that a person has a desire to live, avoiding work, even avoiding the work of living by the commandments. People will create a society in which it will be impossible to find Christ. $\mathrm{He}$ notes that the kingdom of the Antichrist is maturing in human society, it does not arise miraculously from the depths of darkness.

Next, we should focus on the interpretation of the "Revelation" in the Catholic tradition.

At the beginning of the third millennium, the whole civilization found itself at the epicenter of global processes, which are increasingly becoming

\footnotetext{
${ }^{3}$ Mariia BARDYN, "Apocalyptic Reflections in the Studies of the Russian Orthodox Priest Alexander Men,” Skhid, no. 5 (2019): 67-71.

${ }^{4}$ Andrey KuRAEV, Rannee khrystyanstvo y pereselenye dush, 2nd ed. (Moscow: Sreten monastyr, 1998), 336.
} 
antagonists, based on the idea of the infinity of human existence, axiological landmarks that have so far filled all forms of culture.

Today, humanity is on the verge of a catastrophe, the cause of which is the human factor, the "creative mind," the thoughtless human activity that threatens to destroy.

All this forces man to rethink his own activities, purpose, and the values he professes. Man needs to rethink the key principles of the Western cultural tradition: the development and effectiveness of science and technology, the use of natural resources, the development of nature, pragmatism, and others. Over time, the need to move to a new level of human self-awareness, what mission, the role it plays in social progress, a person must reconsider their own moral and value guidelines of their activities. In the context of the research, it is necessary to analyze the social doctrine of Catholicism, which is based on the mastery of theo-humanism, that is, the recognition of man as one who was created in the image and likeness of God.

It is necessary to make a detailed analysis of the position of the Catholic Church on the causes and manifestations of modern global problems and the Catholic understanding of possible ways to solve them.

The source of this study were encyclicals, epistles of popes John XXIII, Paul VI, John Paul II, Benedict XVI, and the works of Catholic theologians, in particular, J. Mike, which provide a theological understanding of modern global problems, their sources, and means of overcoming them. ${ }^{5}$

The social encyclical of John XXIII's Mother and Mentor is a reaction to large-scale changes in science, technology, economics, socio-political life, and a certain attempt to rethink them and make recommendations to Catholics around the world about their socio-political activities. Besides, John XXIII pays attention to the problem of the disproportion of the socio-political development of peoples, which provoked modern social problems that have become global.

Given the principles of Christian humanism, personalism, natural law, the common good, the humane structure of society, and the proportionality of social development, John XXIII emphasizes the socio-educational moment and offers specific courses of action. ${ }^{6}$

\footnotetext{
${ }^{5}$ Oksana, VOLYNETS, "Hlobalni problemy suchasnosti z pozytsii katolytsyzmu," Ukrainska natsionalna ideia: realii ta perspektyvy rozvytku 25 (2013): 16-20.

${ }^{6}$ Yuzef MAIKA, Sotsyalnoe uchenye Katolycheskoi Tserkvy (Rome-Lublin: Yzdatelstvo Sviatoho Kresta, 1994), 479.
} 
John XXIII's encyclical Peace on Earth is imbued with concern for peace throughout the world. In his study of the Cold War and the threat of nuclear war, the pope sees a gap between politics and morality and emphasizes that these problems are primarily the consequences of a moral problem. A necessary condition for peace, according to John XXIII, is harmony and order in the world, based on natural law, the source of which is the Eternal Law. Also, the encyclical deals with four specific principles - truth, justice, love, and freedom, ${ }^{7}$ which can be confidently called the fundamental principles of social life.

The globalization of modern social problems has highlighted the need to reconsider the role of international organizations in solving them. Roman pontiffs, in particular Paul VI and his successor John Paul II, raise the question of the impossibility of manipulating international organizations to ensure the interests of a particular state. They emphasize the need for agreed political decisions and effective performance of functions of control and leadership. ${ }^{8}$

The end of the twentieth century became a transitional stage from postChristian culture to the era of post-Christian civilization with all its consequences. Scientific and technological progress and new achievements have become the key to changes in the foundations of life, changes in both social and existential conditions of human existence. Mankind itself has created global problems, and man has found himself on the path to overcoming these problems, although this challenge is quite complex and controversial.

Analyzing the global problems of our time, John Paul II complements the teachings of previous Roman pontiffs. For example, the situation in Europe in the late twentieth century is evaluated by John Paul II not as peace, but as the absence of war. Scientific and technological progress, which should promote development, was instead aimed at the production of weapons of mass destruction.

The principle of humanity requires people to respect and recognize the dignity of each person. In the context of the problem of struggle, the question of war and peace, it takes the form of commitments aimed at protecting the civilian population from the effects of struggle, conflict, and war. Refugees are considered to be a special group of victims of the struggle, because of the

\footnotetext{
${ }^{7}$ NyKodym, Yoann, Papa Rymskyi (Vienna, 1984).

${ }^{8}$ JOHn PAUL II, Apostolskyi lyst na pochatku novoho tysiacholittia (Kyiv: Vydannia sekretariatu Synodu Yepyskopiv Ukrainskoi Hreko-Katolytskoi Tserkvy, 2006), 59.
} 
fighting they have to leave their native land and seek another asylum, far from their homeland.

Addressing the question of the coexistence of different cultures in a pluralistic world, Benedict XVI argues that innovative armed confrontations from time to time take on the character of interfaith conflict. Religion must in no way fence off war and intolerance and use coercion in the name of the Lord. Religion is designed to shape moral and ethical activities. In particular, in the encyclical "The Hundredth Year" John Paul II states that caring for the environment is probably a challenge for the whole mankind, a common and universal commitment to respect the common good. ${ }^{9}$

Thus, global difficulties from the period of their emergence to this day remain in the field of view of the Catholic Church. Their preconditions and results were systematically studied and analyzed in all official documents of the Roman bishops. Certainly, they are not limited to the problems of war and peace or environmental protection. Their list is much more extensive and requires further study. But the Catholic Church's view of the factors of emergence and results for humanity is based on the positions of theocentrism and theo-humanism.

The Catholic Church considers the source of all modern problems and threats to be the immorality of the world, the development of inhumane ideologies, and the primacy of the atheistic worldview. The Catholic Church calls for a rethinking of socio-political reality and its configuration based on responsibility, solidarity, and the common good.

Today's Western European and Ukrainian cultural process is in active search of spiritual values that can ensure the stable formation and development of society and culture in the future. During the decline and global rethinking of strategies and possible directions of culture, man turns to the reappraisal of spiritual intentions; one of the forms of rethinking is alarmism - a sense of anxiety, fear of extinction, or trying to get used to human mortality. The presence of various relationships of alarmism with cultural processes studied in the humanities leads to the need for a detailed study rethinking the essence of this multifaceted process, because only the consciousness and explanation of the cultural phenomenon, says Karl Barth, deprive him of "ideological power influence."

\footnotetext{
${ }^{9}$ BenEDICT XVI, Entsyklika “Liubov u pravdi” (Zhovkva: Misioner, 2010), 128.

${ }^{10}$ Yuliya MALIKOVA, "Metodolohichni zasady doslidzhennya alarmizmu yak kulturnoho fenomenu," Voprosy dukhovnoy kultury - KULTUROLOGIYA, no. 265 (2013): 143-46.
} 
The time of formation of the subconscious immanent self-feeling of horror is similar to the time of development of postmodernism, one of the priority features of which is the apocalyptic worldview, the growing importance of the intensification of eschatological premonitions. The special worldview inherent in the transitional epochs, the uncertainty of possible ways of future historical formation in the situation of "God's death" (Friedrich Nietzsche), the understanding of the exhaustion of science, technology, progress led to anthropological, "human crisis" (Karl Jaspers), (Romano Guardini), the disappearance of spiritual intentions.

One of the features of the formation and development of the world is considered to increase the scale of events, strengthen the internationalization of social processes, their desire to become more massive and global in nature, that is, covering the whole world, all mankind and each person in particular.

In Christian globalism, there are two different directions of understanding and solving the global problems of our time, which are characterized, on the one hand, by apocalyptic alarmism and social pessimism, and on the other, by Christian solidarity and social realism.

Apocalyptic alarmism and social pessimism. Pessimistic predictions of mankind, developed in the 60s and 70s under the auspices of experts from the so-called Club of Rome, were perceived by some Christian, mostly Protestant, theologians in the West as a new version of the Apocalypse. The conclusions of the Club of Rome on the negative consequences of the progressive scientific and technological revolution (STR) are as follows: planned in critical, and hence threatening to human existence, indicators of depletion of natural resources, environmental pollution, "population explosion," and hencethe inevitable famine, etc. used to inject the apocalyptic state of mankind.

The results of research and forecasts of the Club of Rome in theological reasoning in scientific forms and with hyperlinks to the authority of worldrenowned sociologists, demographers, economists, and politicians, raised eschatological questions about the inevitability of a catastrophe. The relationship and interdependence of crises (overpopulation of individual areas, environmental pollution, raw materials, energy, food decay, and other mass accidents and actions) are becoming massive and global. And on this basis apocalyptic theologians have created theological concepts of the globality of the negative results of STR for the whole mankind. Authors of theological concepts of the future, futurologists, and researchers predicted the "irreversible degradation of mankind."

Next, it is worth focusing on the Protestant interpretation of the last days. 
The apocalyptic and prophetic nature of the principles of the SDA Church is enshrined in a series of twenty-seven "Fundamentals of the Seventh-Day Adventist Christian Doctrine," adopted in Dallas at the April 1980 World Congress. The general apocalyptic positions of Adventists are set out in the section "The Doctrine of Recent Events" of the fundamental doctrinal publication "In the beginning was the word," which analyzes such phenomena as the second coming of Christ, death and resurrection, the Millennium Kingdom, and the New Earth. ${ }^{11}$

Substantiating the doctrine of the end of the world in the context of the linear development of history, Adventists define it as a period of a great struggle between good and evil, the ultimate goal of which is to establish the Kingdom of eternity.

Applying the biblical concept of history: the creation of the world, the first and second coming of Christ, Adventists believe that through these three milestones it is possible to draw a timeline: this will be a path to the goal the Kingdom of God. They believe that biblical prophecies, from the very beginning of this journey to its completion, are similar to instructions that tell believers where they are in the flow of time and what awaits them soon. Therefore, Adventists, on the one hand, examine biblical prophecies and their fulfillment as signs of the coming Lord's Day; on the other hand, they make prophecies a methodological principle of their teaching.

An analysis of Adventist sources makes it possible to capture their concept as follows:

- the second coming of Christ, preceded by judgment,

- the first resurrection and ascension of the saints,

- Armageddon, the desolation of the earth and the destruction of the wicked,

- the 1,000-year kingdom of the righteous in heaven,

- the second resurrection and the last judgment,

- the New Land.

As the name of the church suggests, Adventists focus on the second coming (Advent) of Christ. Therefore, this category can be considered key in their doctrine. It was developed by William Miller and Ellen White. It is worth noting that Miller predicted that the Second Coming of Christ would occur in 1884, due to people's failure to abide by his prophecies, there was a "great

\footnotetext{
11 Mariia BARDYN, “Apokaliptychni ochikuvannia v suchasnii relihiinii literaturi Svidkiv Yehovy ta Adventystiv somoho dnia (porivnialna kharakterystyka), Skhid, no. 3 (2017): 53-57.
} 
disappointment." After such a mistake, Miller and his followers no longer tried to determine the date of Christ's coming.

Thus, the peculiarities of the Adventist understanding of the last days are: the doctrine of the literal Millennial Kingdom of the resurrected and the living righteous in heaven with a complete devastation of the earth, the principles of conditioning (mortality of soul), and annihilationism (rejection of the doctrine of eternal torment). ${ }^{12}$

The Adventist course "Exploring the Word of God" addresses the question: Does God have a special message for Christians living in the last days?

Scripture has a special significance in our time, Adventists say. This threefold message is presented in the book of the Revelation of John the Theologian (Rev. 14:6-16). It is announced by three angels, and its culmination is connected with the Second Coming of Christ (Rev. 14-16).

Adventists claim that the Bible contains many prophecies about the return of Jesus. This event is also identified with the "end of the world" or the "end of time" because it is at this point that Jesus will put an end to everything that has gone the way of sin since the creation of the world. Jesus told his disciples and followers what the signs of the end of the world were:

- False prophets will appear in the world who claim that they can give people salvation.

- There will be wars, periods of famine, and many earthquakes.

- Believers will be hated, arrested, and killed.

- Many false prophets will deceive people, and anger, hatred, and sin will spread throughout the world.

- The gospel will be preached throughout the world.

Today, in some countries, believers in Jesus are persecuted, imprisoned, tortured, and often executed. Many believers are forced to worship Him secretly and share their faith with others, risking their own lives. And although in most countries the situation in this regard is still quite fortunate, Jesus said that at the end of time, the persecution of believers will intensify.

The last sign of the approaching end of the world, called Jesus, is a joyful sign, Adventists say. The good news of His coming and His plan of salvation will be proclaimed throughout the world. Never before has the Gospel been preached in almost every corner of the world. Today, when access to the Internet is possible from any mobile phone, people can read or hear about Jesus no matter where they live or what language they speak.

\footnotetext{
${ }^{12}$ Ibid.
} 
So, is this really the end time? Will Jesus come soon? Yes, soon, although not all signs have yet come true, Adventists say.

The biblical book of the Revelation of John the Theologian is replete with prophecies about future events. The last time in Earth's history will be the most exciting and at the same time the most frightening. The day will come when almost all religious movements will finally renounce the truth. People will preach lies and claim to speak on behalf of God. True followers of Jesus at this time will live in fear, fearing for their lives. The coming of this time will be a clear sign that Jesus is about to return.

Thus, humanity will be able to see His return in the clouds. Elsewhere in the Bible, it is also emphasized that Jesus will come in the clouds. The book of the Revelation of John the Theologian states: "Behold, he cometh with clouds, and every eye shall see him" (Rev. 1:7). Thus, the coming of Christ will not be a secret event as everyone will be able to see Him.

God's saving operation will end when Jesus returns to earth and puts an end to sin, pain, and death. And then all who have faithfully followed Him in earthly life will be with Him to live the life He promised to give them. But this is not the end of the story. Mankind began this journey with the creation of the world. And now we come to the moment of its transformation.

At all times, people have been afflicted by various diseases. Spreading by contact or airborne droplets, diseases were transmitted from person to person, infecting more and more people. The rapid spread of viruses can be seen on the example of a business center or school. It is enough for one sick employee or student to get in touch with the team, and soon there will be a second, third, and so on, and after a while, almost the entire team will be in need of medical care.

With the development of technology, new types of viruses have emerged that are spreading even faster. They do not impress people, but affect them, disabling technology. These viruses reach their goal very quickly.

Nowadays, computer virus infections sometimes threaten us more often than diseases. In a world where much of what we do depends on the computer, the destructive power of such a virus can turn the complete chaos of the entire system we rely on into our work.

Adventists say the purpose of the Bible is not to inform, but to transform us. It is almost impossible to read the Bible and remain indifferent to it. Reading this book provokes a variety of reactions. For centuries it was loved and hated, unconditionally believed, and ruthlessly criticized. Faith and 
observance of God's commandments are signs of the true Church (Rev. 12:17; 14:12).

The miracle of the Bible is that it does not delve into theories and concepts. Its teachings surpass any philosophy, and they are directly relevant to our daily lives. It teaches us to live, to cope with our life dramas and conflicts, to resolve emerging issues, as Adventists say. Faithful people are called to live in righteousness (Rev. 18:4). The stories described in the Bible took place with ordinary people who wanted to know the truth. This can happen in your life, if, putting aside superstition, you continue to study the exciting Book of Books - the Bible.

In the Bible, God reveals the way He leads His people. Thanks to the Bible, we can distinguish the true church from the false one, Adventists emphasize. We need to be able to show signs of deviance from religion (Rev. 17:1-5).

Baptists believe that the doctrine of the millennial kingdom (chiliasm) has never been generally accepted in the Church. When referring to (Rev 20), they offer two existing concepts about him: 1) the reign of Christ for a thousand years on Earth; 2) the reign of Christ in the Kingdom of Heaven. Pentecostals, in turn, distinguish the millennial reign of Christ with the elect into two periods: 1) at the beginning of the thousand years - on Earth (Rev. 20: 1-10); 2) later, "from age to age," in heaven (Rev. 11:15; 25:5).

Jehovah's Witnesses, like Adventists, are convinced that Jesus Christ will create the millennial Kingdom of Heaven with His elect (Rev. 4:4) to prepare Earth and man for eternity. According to them, it was already launched in $1914 .{ }^{13}$

The understanding of Jehovah's Witnesses in the last days is illustrative. Although there is controversy over their affiliation with Protestantism, Jehovah's Witnesses themselves refer to themselves as Christians, with some researchers emphasizing that they belong to marginal Protestantism. Protestant churches deny that a religious organization of Jehovah's Witnesses belongs to Christianity because they do not accept the basic religious doctrines of universally recognized Christianity and do not participate in religious traditions of non-biblical origin.

However, we consider it appropriate to use their interpretation of the Apocalypse within this study and classify them as neo-Christians. Jehovah's Witnesses define "the end" as the end only for this world and the transition to another dimension, the theocratic kingdom of Jehovah, as its sovereign right.

\footnotetext{
${ }^{13}$ Vasiliy KonYK, Krytyka eskhatolohyy Svydetelei Yehovy (Moscow: Znanye, 1976).
} 
They associate the "end of time" and subsequent events with the second coming of Christ. Therefore, at the center of their teaching is the prophetic chronology of the coming of Christ, the resurrection of the saints, the ascension of the anointed into heaven. ${ }^{14}$

In general, conceptually the prophecies about the end of the world are covered in the series of the "Millennium Star" publishing house in the following books: "The Time is Near," "Let Thy Kingdom Come."15 The modern interpretation of eschatology is given in two doctrinal publications: "Jehovah's Witnesses are Heralds of the Kingdom of God" and "Revelation. Its Majestic Apogee Is Near!". A special difference of the eschatology of the Witnesses is the doctrine of 1914 as the date of the beginning of the active reign of Christ. ${ }^{16}$

The basic tenets of this religion include: provisions on two classes of Christians, hope for heavenly life for the 144,000 elect, the special place of the "class of the faithful and prudent slaves" in the person of the Council, rejection of the doctrine of the immortality of the soul, adherence to the theory of annihilationism (rejection of the doctrine of "eternal torment"), and belief in paradise on earth after Armageddon.

Besides, the teaching of the Witnesses is characterized by a constant change in the chronology of the prophetic dates of Christ's coming, the resurrection of the dead, and the establishment of the Millennial Kingdom.

The work of the evangelist, preacher, and writer Timothy Medvedev's "Apocalypse: Simply and Clearly about the Most Mysterious Book of the Bible" is an interpretation of the book Apocalypse addressed to a wide range of readers. The author's hermeneutic approach to interpreting the Apocalypse is a variation of the "futuristic" understanding of the text. At the same time, there are references in the text to the historical context of the book, although they are fragmentary and inconsistent. The interpretation of the text is based on the premise that the book contains prophecies that relate to the realities of life of a modern man living in an era of technological progress. ${ }^{17}$

In the context of our study, it is necessary to consider the main trends in understanding the end of the world in the works of neo-Orthodox.

Among the general principles of neo-orthodox eschatology are: a reinterpretation of the eschatological plots in the Bible, rejection of its apocalyptic

\footnotetext{
${ }^{14}$ E. PraIs, Svydetely Yehovu (Kaliningrad: Yantar, 1994), 176.

${ }^{15}$ Ibid.

${ }^{16}$ Martin Chemnitz, Kliuchevue voprosbl bohoslovia, vol. 2 (Moscow: Lyuteranskoye naslediye, 2003), 1064.

${ }^{17}$ Aleksandr BELIAEV, “Apokalypsys: prosto y poniatno o samoi zahadochnoi knyhy Byblyy," Bohoslovskye razmyshlenyia, no. 20 (2008): 224-27.
} 
elements, an attempt to combine the biblical apocalyptic with revolutionary utopia, and social teachings. The main idea of modern neo-Orthodoxy is that the Kingdom of God has already been established with the first coming of Christ, and the final realization of all Christ's promises will be in the future, for which the world should be prepared by changing it ethically and socially.

The Protestant theologian Karl Barth, referring to the New Testament, sees the resurrection of Christ as a sign that God in the person of his Son has already won the final victory in favor of man. ${ }^{18}$ The Paschal message thus means that man's enemies - sin, curse, and death - are destroyed, and eschatology culminates in the resurrection of Christ. Bart consistently adheres to the principles of "realized eschatology," removing its apocalyptic future.

Rudolf Bultmann (1884-1976), a well-known exegete and specialist in systematic theology, attempted to translate the eschatological mythical plots of the Bible into plain language, "demythologization."

He believes the twentieth-century theology needs a conceptual apparatus to make the New Testament Revelation available to modern man. Mythical eschatology, according to Bultmann, is becoming impossible today because, contrary to the biblical prophecy of the second coming of Christ, world history continues to evolve. Bultman is convinced that people no longer associate the end of the world with the Second Coming, but with natural disasters.

Several ideas of neo-orthodox modernism and reformism can be attributed to the research work of the German religious philosopher and theologian Paul Tillich (1886-1965). He, on the one hand, seriously rethought eschatology in the context of the theology of history and therefore saw the "end of history" not as an apocalyptic collapse of earthly existence, but its "overcoming" through social change; on the other hand, Tillich raised the question of reinterpretation of eschatological plots of the Gospel, which would help modern people to understand the news of the coming of Christ. ${ }^{19}$

The German theologian Jürgen Moltmann was convinced that eschatology was not just a collection of events that were to take place at the end of time, but a factor that gave shape to all Christian theology. Therefore, he does not reduce eschatology only to the "last days," but puts it at the center of theology.

The problem of perception of the book as a whole is also indicative. The original thesis of the monograph of the Protestant Bible researcher Mark

\footnotetext{
${ }^{18}$ Karl BARTH, Ocherk dohmatyky: Lektsyy, prochytannble v unyversytete Bonna v letnyi semestr 1946 h. trans. Y. A. Kemelova (Saint Petersburg: Aleteia, 1997), 272.

${ }^{19}$ Anyur KARYMSKYI, Teolohyia ystoryy y realnost: K krytyke protestantskoi eskhatolohyy (Moscow: Znanye, 1985), 64.
} 
Stephens is presented by the author in the title of the work Annihilation or Renewal? ${ }^{20}$

The urgency of addressing the new creation in the Apocalypse is due to the apparent lack of agreement in the scientific literature on which of the two alternative eschatological scenarios (respectively, the destruction or renewal of the world) is preferred by the author of the Revelation of John the Theologian.

It should be noted that the methodological basis of this work is the historical-critical method. Stephens emphasizes that the book "Revelation" focuses on the formation of a holistic Christian worldview.

Returning to the original thesis, Stephens notes that the answer must be sought in the text of the Apocalypse: "creation is not abandoned, but rather it is raised to a qualitatively higher level, where its original goals and objectives are fully fulfilled. The new creation differs from the old by the absence of forces that bring with them destruction, pain, and chaos, as well as the full and direct presence of God, because previously opposed to each other heaven and earth merge into one inseparable unity."

Thus, the prophecies and sayings of the Apocalypse are aimed at the audience of Christians in Asia Minor, designed to inform both about the judgment of the current state of creation, and about the eschatological renewal of the world. Accordingly, the update itself is the answer to the main question of the work of Stephens.

The imagery of a space battle in heaven and on earth seems fascinating for researchers. However, much controversy surrounds the correct interpretation of this book. Researchers identify the main problematic questions: Who is this book addressed to? Does the book contain prophecies about future events, or were they already fulfilled in the first centuries?

\section{CONCLUSION}

As a result of the transformation of apocalyptic doctrines, modern forms of adaptation of apocalyptic doctrines to the requirements of the social environment have emerged. A positive moment in this process is the incentive for a person to rethink their life - its situational change towards respect, care,

\footnotetext{
${ }^{20}$ Mark B. STEPHEns, Annihilation or Renewal? The Meaning and Function of New Creation in the Book of Revelation (Tübingen: Mohr Siebeck, 2011), 343.
} 
charity, love of neighbor. The development of eschatological teaching in modern conditions has intensified such a field of scientific knowledge as futurology, which actively studies the transforming processes taking place in the human environment and predicts the future.

The apocalyptic problem is multidimensional, multifaceted in its value, and socially significant potential. The biblical texts that speak of the "end of the world" can be understood in different ways, as the analyzed Orthodox, Catholic, Protestant apocalyptic concepts focus on one or another important aspect of the biblical Revelation.

\section{BIBLIOGRAPHY}

BARDYN, Mariia. “Apokaliptychni ochikuvannia v suchasnii relihiinii literaturi Svidkiv Yehovy ta Adventystiv somoho dnia (porivnialna kharakterystyka)." Skhid, no. 3 (2017): 53-57 | Бардин, Марія. «Апокаліптичні очікуванніа в сучасніі релігіініі літературі Свідків Єгови та Адвентистів сомого дніа (порівніална кгарактеристика)». Сxid, № 3 (2017): с. 53-57.

BARDYN, Mariia. "Apocalyptic Reflections in the Studies of the Russian Orthodox Priest Alexander Men." Skhid, no. 5 (2019): 67-71.

BARTH, Karl. Ocherk dohmatyky: Lektsyy, prochytannble v unyversytete Bonna v letnyi semestr 1946 h. Trans. Y. A. Kemelova. Saint Petersburg: Aleteia, 1997| Барт, Карл. Очерк догматики: Лектсии, прочитанные в университете Бонна в летнї семестр 1946 2. Пер. Ю. А. Кемелова. Санкт-Петербург: Алетейя, 1997.

Beliaev, Aleksandr. "Apokalypsys: prosto y poniatno o samoi zahadochnoi knyhy Byblyy." Bohoslovskye razmblshlenyia, no. 20 (2008): 224-27 | Беліаев, Александр. «Апокалипсис: просто и поніатно о самоі загадочноі книги Библии». Богословскє размышленїа, № 20 (2008): с. 224-227.

Benedict XVI. Entsyklika "Liubov u pravdi." Zhovkva: Misioner, 2010 | Бенедикт XVI. Енцикліка «Любов у Правді». Жовква: Місіонер, 2010.

Chemnitz, Martin. Klyuchevyye voprosy bogosloviya. Vol. 2. Translated by Konstantin Komarov. Moscow: Lyuteranskoye kulturnoye naslediye, 2003 | Хемниц, Мартин. Ключевые вопросы богословия. Том 2. Пер. Константин Комаров. Мосkbа: Лютеранское культурное наследие, 2003.

HolovashChenko, Serhiy. Doslidzhennia ta vykladannia Biblii v Kyivskii dukhovnii akademii $X I X$ - pochatku XX st. Kyiv: Vydavnychyi viddil Ukrainskoi Pravoslavnoi Tserkvy, 2012 | Головашченко, Сергій. Дослідженніа та викладанніа Бібліі в Кївскіi дукговніi академіi XIX-початку XX cm. Київ: Видавничї відділ Украінскоі Православноі Церкви, 2012.

DoKASH, Vitaliy. "Nova ortodoksiia yak rukh za modernizatsiiu eskhato-soteriolohichnykh doktryn khrystyianskoho vchennia." Relihiia ta Sotsium, no. 2 (2013): 5-10 | Докаш, Віталіи. «Нова ортодоксііа як рукг за модернізатсііу ескгато-сотеріологічникг доктрин кгристїанского вченніа». Реліzіiа та Соціум, № 2 (2013): с. 5-10.

John PAUL II. Apostolskyi lyst na pochatku novoho tysiacholittia. Kyiv: Vydannia sekretariatu Synodu Yepyskopiv Ukrainskoi Hreko-Katolytskoi Tserkvy, 2006 | Іван Павло II. 
Апостолскї лист на початку нового тисіачоліттіа. Київ: Виданніа секретаріату Синоду Єпископів Украінскоі Греко-Католитскоі Церкви, 2006.

KARYMSKYI, Anyur. Teolohyia ystoryy y realnost: K krytyke protestantskoi eskhatolohyy. Moscow: Znanye, 1985 | Каримскї, Анюр. Теологїа истории и реалност: К критике протестантскоі ескгатологии. Моckba: Знание, 1985.

KonYк, Vasiliy. Krytyka eskhatolohyy Svydetelei Yehovy. Moscow: Znanye, 1976 | Коник, Василий. Критика эсхатологии свидетелей Иеговы. Mockba: Знание, 1976.

Kuraev, Andrey. "Pokolenye Apokalypsysa" S. 40-47.

KuRAEv, Andrey. Rannee khrystyanstvo y pereselenye dush. 2nd ed. Moscow: Sreten monastyr, 1998 | Кураев, Андрей. Раннее христианство и переселение душ. 2-е изд. Мockba: Сретен. Монастырь, 1998.

MAIKA, Yuzef. Sotsyalnoe uchenye Katolycheskoi Tserkvy. Rome-Lublin: Yzdatelstvo Sviatoho Kresta, 1994 | Майка, Юзеф. Социальное учение католической церкви. Рим-Люблин: Издательство Святого Креста, 1994.

MALIKOVA, Yuliya. "Metodolohichni zasady doslidzhennya alarmizmu yak kulturnoho fenomenu." Voprosy dukhovnoy kultury - KULTUROLOGIYA, no. 265 (2013): 143-46 | Малікова, Юлия. «Методологічні засади дослідження алармізму як культурного феномену». Вопросы духовной культуры - КУЛЬТУРОЛОГИЯ, № 265 (2013): с. 143-146.

Men, Aleksandr. Chytaia Apokalypsys. Moscow: Fond ymeny Aleksandra Menia, $2000 \mid$ Мень, Александр. Читая апокалипсис. Москва: Фонд имени Александра Меня, 1999.

NyKodym. Yoann XXIII, Papa Rymskyi. Vienna, 1984.

"Obiavlennia. Yoho velychnyi apohei vzhe blyzko!" New York: Watchtower Bible and Tract society, 1995.

Petryshyn, Neonila. Interpretatsiia ekolohichnykh problem u katolytsyzmi. Zhytomyr: Zhytomyr Ivan Franko State University, 2016 | Петришин, Неоніла. Інтерпретатсіia екологічникг проблем у католитсизмі. Житомир: Житомирський державний університет імені Івана Франка, 2016.

Prais, E. Svydetely Yehovu. Kaliningrad: Yantar, 1994 | Праіс, Е. Свидетели Єгову. Калининград: Янтар, 1994.

RAtZinger, Joseph. Tsinnosti $v$ chasy peremin. Dolannya maybutnikh vyklykiv. Translated by O. Konkevych. Lviv: Misioner, 2006 | Рацінгер, Йосиф. Цінності в часи перемін. Долання майбутніх викликів. Пер. О. Конкевич. Львів: Місіонер, 2006.

Stephens, Mark B. Annihilation or Renewal? The Meaning and Function of New Creation in the Book of Revelation. Tübingen: Mohr Siebeck, 2011.

VOLYNETS, Oksana. "Hlobalni problemy suchasnosti z pozytsii katolytsyzmu." Ukrainska natsionalna ideia: realii ta perspektyvy rozvytku 25 (2013): 16-20 | Волинетс, Оксана. «Глобалні проблеми сучасності $з$ позитсіі католитсизму». Украінска натсіонална ідеіа: реалї̈ та перспективи розвитку 25 (2013): с. 16-20.

\section{CONFESSIONAL POLYVARIANCE OF CHRISTIAN APOCALYPTIC: COMMON AND DISTINCTIVE FEATURES}

\section{Summary}

The twentieth century was a time of active expansion of Christian culture throughout the world. The Catholic and some Protestant churches resorted to this. This culture, becoming global, accommodated, and united a large number of cultural and religious minorities. At the same time, promoting its uniqueness, it could not always confirm her identity. 
One of the characteristic features of the development of the modern world is an increased scale of events, greater internationalization of social processes, and their tendency to become global. Based on all modern problems, in the sense of their understanding and solution, Christian globalism were formed as a component of the doctrine of Christian denominations, which includes a full range of different concepts and ideas that reflect the typical human problems of modern civilization.

Since Christian eschatology is confessionally multivariate, it makes sense to explore both the characteristics common to all denominations and specific to some of them, as well as to identify transformational models and forms of adaptation of eschatological ideas to today's realities.

The actualization of the problem of moral-ethical and social aspects of Catholic eschatology, Christological-apocalyptic visions of Orthodox eschatological teaching, and the apocalyptic-prophetic character of Protestant eschatology in their transformational manifestations was designed to impart on the paper both theoretical and socio-practical significance.

Keywords: apocalyptic; Orthodoxy; Christianity; theology; crisis; Bible; Revelation.

\title{
WYZNANIOWE ZRÓŻNICOWANIE APOKALIPTYKI CHRZEŚCIJAŃSKIEJ: CECHY WSPÓLNE I ODRÓŻNIAJĄCE
}

\author{
Streszczenie
}

Wiek XX był czasem aktywnej ekspansji kultury chrześcijańskiej na całym świecie, również za sprawą Kościoła katolickiego i niektórych Kościołów protestanckich. Kultura ta, stając się globalną, objęła i zjednoczyła dużą liczbę mniejszości kulturowych i religijnych. Pomimo swojego wyjątkowego charakteru, nie zawsze jednak potrafiła potwierdzić swoją tożsamość.

Jedną z charakterystycznych cech rozwoju współczesnego świata jest występowanie wszelkich wydarzeń w wielkiej skali, większe umiędzynarodowienie procesów społecznych i tendencja do ich globalizacji. Pod względem rozumienia i rozwiązywania problemów, które niesie współczesność, globalizm chrześcijański stał się elementem doktryny wyznań chrześijańskich, obejmując szeroki wachlarz różnorodnych koncepcji i idei odzwierciedlających typowo ludzkie problemy współczesnej cywilizacji.

W związku z tym, że eschatologia chrześcijańska obejmuje różne wyznania, zasadnym jest zbadanie zarówno cech wspólnych dla wszystkich denominacji, jak i tych specyficznych dla niektórych z nich, a także określenie transformacyjnych modeli i form adaptacji idei eschatologicznych do dzisiejszych realiów.

Aktualizacja problematyki moralnej, etycznej i społecznej eschatologii katolickiej, chrystologiczno-apokaliptycznych wizji prawosławnego nauczania eschatologicznego oraz apokaliptyczno-profetycznego charakteru eschatologii protestanckiej w ich transformacyjnych przejawach w zamierzeniu autorki nadaje prezentowanej pracy wymiar zarówno teoretyczny, jak i społeczno-praktyczny.

Słowa kluczowe: apokaliptyka; prawosławie; chrześcijaństwo; teologia; kryzys; Biblia; Objawienie. 